○清水祐二、竹越哲男、小池宣之、伊藤文英、龟开民雄

(群馬大学耳鼻咽喉科)

心因性難聴は大部分は雨側性で、左右差のほとんどない中等度以上の聴力障害を認める ことが多い”。片侧に既存の器質的難㯖が存在する場合は、心因性難聴がこれに加重される こともある(overlay) ${ }^{2 y}$ 。また、心身症の器官選択の要因の一つとして、過去に睢患した耳 疾患への逃避のこともある3；。今回、我々は片侧性小耳症（鎖耳）の患者に心因性難聴を合 㴊した症例を経験したので報告する。

《症例》

\title{
16 才女姓
}

主訴：左難聴・耳鳴・耳閉感

既往糜 : 右小耳症 (鎖耳) があり、6才までに耳介形成術を揓行。小児嘴息、十二指腸

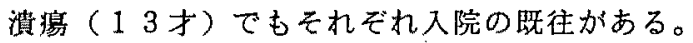

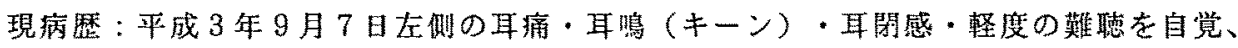
頭痛も訴えた。9月12 日某病院耳鼻科を受診。当初、左 $35-50 \mathrm{~d}$ B の感音性難聴、 右 (小耳症例) $100-105 \mathrm{~d} \mathrm{~B}$ の湿合性難聴を認めたため、左突発性難聴の診断にて 入院。そこでステロイド・低分子デキストラン等で治療されるも改善せず、耳鳴の大きさ・ 聴力も日によって変動するため、9月 30 日精查・追加治療（高压酸素療法を含む）の目 的で当科に転院となった。

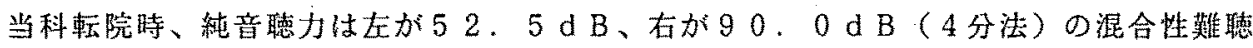
を示したが（図1，a）、会話に対する反応は験者が口を隠していても極めて良好なため、 心因性難聴が疑われた。

Békésy audiometry ( 10 月6日) : 左耳でJergerI型 speech audiometry (10月 17 日) : t左耳でSR T : 46 d B、S D S : 100\% (60d B)

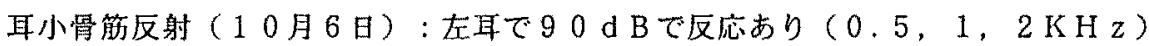

A B R（10月 3 日）：左耳で $30 \mathrm{~dB}$ B で $\nabla$ 波を認めた。

以上より、左耳は機能性難聴と診断し、患者・家族へ病態の説明を行うとともに、治療 としてさらに暗示療法も行った。その後、聴力は小耳症侧も非小耳症侧とほほ並行して徐 々に改善を認め、最終的には平均聴力が左 $13.8 \mathrm{~d} \mathrm{~B}$ 、右 $71.3 \mathrm{~d} \mathrm{~B}$ まで改善し（図 $1, \mathrm{~b})$ 、左側の自覚症状も消失した。その後の経過観察でも再発は認めていない。発症 以来の全聴力の経過 ( $1 \mathrm{~K} \mathrm{H} \mathrm{z}$ ) を図 2 に示す。尚、視野狭窟等の視力障害は訴えず、特 別に心因上なりうるようなものもなかった。しかし、右耳が小耳症でほとんど聞こえない ため、左耳の聴力に強い不安を持っていた。

\section{《考察》}

本例の難聴は、患者に意識的過程は認められず、詐聴とは区别され、最終的に心因性難 聴と診断された。一方、家族・校友関係・学業等にも問題点は見いだせず、性格上の問題 点も明らかにできなかった。しかし、小耳症（鎖耳）があり、難聴や外見に対する不安感 は常に存在すると思われる。1 3 才封に十二指腸潰瘍で入院しているが、ストレスの関与 が否定できない。また、患者の母親がたまたま前医の看護婦であり、良聴耳に対する注意 
が過度になったことも誘因となりえたと考えられる。

本例のように片側に既存の器質的難聴が存在し、その難聴が高度な場合、患者の意識は 左右耳で異なることも考えられるが、本例では小耳症侧にも健侧と同程度の難聴が加重さ れ、暗示療法により健側聴力とほぼ並行して改善した。かかる加重現象の発現理由は中枢 性機序に求められるが、殊に、中枢における音に対する認識の域値の上㫤が考えられる。 しかし、C N V 聴力検查の報告によれば、心因性難聴と詐聴との本質的区別は困難である という4)。

《まとめ》

1) 片側性小耳症（鎖耳）患者に心因性難聴の合併がみられた。

2 ) 自覚症状として健侧の急性難聴の形で発症したが、聴力検查上は両耳の変動性聴力障 害を示した。

3 ) 本例に突発性難聴の治療は無効で、暗示療法が有効であった。

《参考文献》

1.) 水田康雄：心因性難聴の臨床的研究. 耳鼻臨床 77 : $1299-1313$, 1984

2) 古賀慶次郎：心因性難聴の病態。耳喉頭䅡 62（1 1)：975-978，1990

3 ）小林潔子：小児の心因性難聴一症状の特徽と診断の手がかり一。耳㬋 55 (8)

$623-629,1983$

4 ）細田康男：機能性難聴についての検討一C N V 聴力検查を用いてー。Audiology Japan $31: 264-269,1988$

図 1.

a, 当科転院時聴力

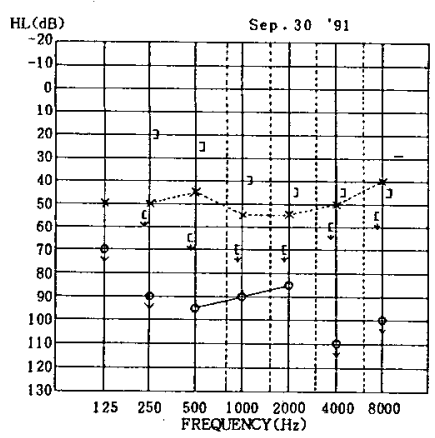

b，最終的な聴力

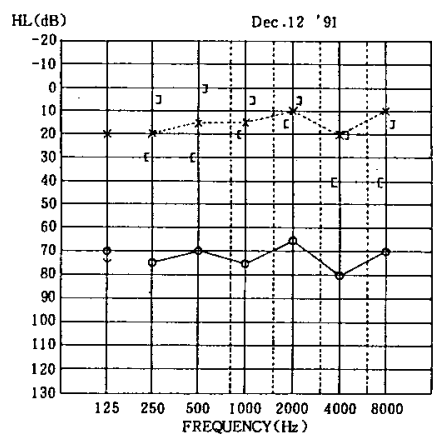

図 2 発症以来の全聴力経過 $(1 \mathrm{KHz})$ $\mathrm{HL}(\mathrm{dB})$

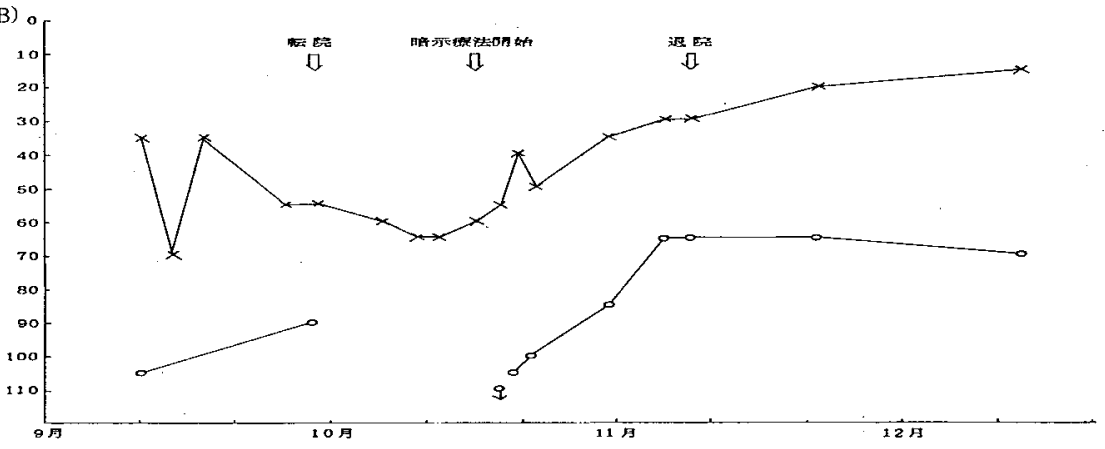

